\title{
Effect of Gaseous Ozone Exposure on the Development of Green and Blue Molds on Cold Stored Citrus Fruit
}

\author{
Lluís Palou, Dept. of Pomology, University of California, Davis, Kearney Agricultural Center, 9240 South River- \\ bend Ave., Parlier, CA 93648; Joseph L. Smilanick, Horticultural Crops Research Laboratory, USDA-ARS, 2021 \\ South Peach Ave., Fresno, CA 93727; Carlos H. Crisosto, Dept. of Pomology, University of California, Davis, \\ Kearney Agricultural Center, 9240 South Riverbend Ave., Parlier, CA 93648; and Monir Mansour, College of \\ Agriculture, Menofiya University, Shebin El-Kom, Egypt
}

\begin{abstract}
Palou, L., Smilanick, J. L., Crisosto, C. H., and Mansour, M. 2001. Effect of gaseous ozone exposure on the development of green and blue molds on cold stored citrus fruit. Plant Dis. 85:632-638.

The effects of gaseous ozone exposure on in vitro growth of Penicillium digitatum and Penicillium italicum and development of postharvest green and blue molds on artificially inoculated citrus fruit were evaluated. Valencia oranges were continuously exposed to $0.3 \pm 0.05 \mathrm{ppm}$ (vol/vol) ozone at $5^{\circ} \mathrm{C}$ for 4 weeks. Eureka lemons were exposed to an intermittent day-night ozone cycle $\left(0.3 \pm 0.01 \mathrm{ppm}\right.$ ozone only at night) in a commercial cold storage room at $4.5^{\circ} \mathrm{C}$ for 9 weeks. Both oranges and lemons were continuously exposed to $1.0 \pm 0.05 \mathrm{ppm}$ ozone at $10^{\circ} \mathrm{C}$ in an export container for 2 weeks. Exposure to ozone did not reduce final incidence of green or blue mold, although incidence of both diseases was delayed about 1 week and infections developed more slowly under ozone. Sporulation was prevented or reduced by gaseous ozone without noticeable ozone phytotoxicity to the fruit. A synergistic effect between ozone exposure and low temperature was observed for prevention of sporulation. The proliferation of spores of fungicide-resistant strains of these pathogens, which often develop during storage, may be delayed, presumably prolonging the useful life of postharvest fungicides. In vitro radial growth of $P$. italicum, but not of $P$. digitatum, during a 5-day incubation period at $20^{\circ} \mathrm{C}$ was significantly reduced by a previous $0.3 \pm 0.05 \mathrm{ppm}$ ozone exposure at $5^{\circ} \mathrm{C}$ for 4 days. Inoculum density did not influence the effect of gaseous ozone on decay incidence or severity on oranges exposed to $0.3 \pm 0.05 \mathrm{ppm}$ ozone at $20^{\circ} \mathrm{C}$ for 1 week. Susceptibility of oranges to decay was not affected by a previous continuous exposure to $0.3 \pm 0.05 \mathrm{ppm}$ ozone at $20^{\circ} \mathrm{C}$ for 1 week. A corona discharge ozone generator was effective in abating ethylene in an empty export container.
\end{abstract}

Additional keyword: postharvest decay

Postharvest green mold, caused by Penicillium digitatum (Pers.:Fr.) Sacc., and postharvest blue mold, caused by Penicillium italicum Wehmer, are among the most economically important postharvest diseases of citrus worldwide (8). Blue mold is especially important on citrus fruit kept under cold storage for long time periods (30). In California, Valencia oranges for preparation of fresh juice are held at temperatures from 3 to $5^{\circ} \mathrm{C}$. Currently, both diseases are controlled mainly by application of the fungicides imazalil, sodium ortho-phenyl phenate, or thiabendazole (8). Alternative methods are needed because the widespread use of these chemicals in commercial packinghouses has led to the proliferation of resistant strains of the pathogens $(4,7)$. Furthermore,

Corresponding author: L. Palou

E-mail: 1luis@uckac.edu

Accepted for publication 20 February 2001.

Publication no. D-2001-0409-01R

(C) 2001 The American Phytopathological Society concerns about human health risks and the protection of the environment associated with fungicide residues $(5,18)$ have increased the need for alternatives to fungicide usage.

In 1997, ozone, the triatomic form of oxygen $\left(\mathrm{O}_{3}\right)$, was recognized as being generally safe (GRAS) for food contact applications in the United States (10,29). Since that time, interest in developing ozone applications in the food industry has increased, although some regulatory issues about ozone use for this purpose have not been resolved. Currently, a Food Additive Petition has been submitted to the U.S. Food and Drug Administration (US-FDA) that would allow ozone to be used in food contact applications. The current Threshold Limit Value-Short Term Exposure Limit (TLV-STEL) established by the U.S. Occupational Safety and Health Administration (US-OSHA) for ozone is $0.3 \mathrm{ppm}$. This is the level to which healthy individuals can be exposed for $15 \mathrm{~min}$ without suffering irritation or other acute effects. Exposures at this level should not be repeated more than four times per day. Once citrus fruit are stored at low temperature, only a few brief tasks must be done within the storage rooms so that workers do not exceed the USOSHA TLV-STEL. However, concentrations could be higher in export containers, which can stay closed for longer periods of time. Other exposure designs include generation of ozone in day-night cycles to minimize workers' exposure to ozone (23).

Currently, ozone can be generated readily and economically on site. For the postharvest treatment of fresh fruit and vegetables, ozone can be used as a relatively brief prestorage or storage treatment in air or water, or as a continuous or intermittent atmosphere throughout the storage period. Both procedures have recently attracted considerable commercial interest, especially because of the lack of residue on the produce and the possibilities opened by the new regulations.

Effects of ozone in the air of storage rooms on fungal decay, and/or commodity storage potential and quality, have been examined for a variety of fruits and vegetables. There are numerous reports on both the benefits $(3,16,17,23)$ and the lack of benefits $(2,20,22,25,26)$ of ozone. However, early studies involving continuous ozone exposure as a storage treatment were probably conducted before efficient ozone generators and reliable means to control and measure ozone concentrations were available. In 1936, Klotz (15) reported that ozone was unsatisfactory for control of green and blue molds on artificially inoculated navel oranges. Hopkins and Loucks (13) reported in 1949 an increase in stem-end rot, green mold, and some fruit pitting on oranges subjected to high ozone concentrations for several minutes to $4 \mathrm{~h}$. In 1968, Harding (11) concluded that storage of lemons and oranges under $1.0 \mathrm{ppm}$ ozone effectively prevented sporulation of green mold on infected fruit, and moderately reduced the incidence of green mold. Jin et al. (14) reported in 1989 that storage of Wenzhou mandarins under discharge products greatly delayed the process of senescence of fruit without damaging the fruit. Recently, García et al. (9) reported no differences in quality parameters between oranges stored at $5^{\circ} \mathrm{C}$ for 1 month in air or $0.1 \mathrm{ppm}$ ozone.

The objectives of this work were to evaluate the effect of continuous gaseous 
ozone exposure at 0.3 or $1.0 \mathrm{ppm}$, or an intermittent exposure at $0.3 \mathrm{ppm}$ (daynight cycle), on the development of $P$. digitatum and $P$. italicum in vitro and on artificially inoculated citrus fruit stored at low temperature. The ability of an ozone generator to abate ethylene levels (6) was also investigated.

\section{MATERIALS AND METHODS}

Fruit. Oranges (Citrus sinensis (L.) Osbeck), cv. Valencia, or lemons (Citrus limon (L.) Burm.) cv. Eureka, from commercial orchards in the San Joaquin Valley (California), were selected from field bins after harvest, randomized, and used in the experiments before any commercial postharvest treatments were applied.

Inoculum. $P$. digitatum isolate PDM-1 and $P$. italicum isolate PIM-7 were grown on PDA in petri dishes at $25 \pm 1^{\circ} \mathrm{C}$ for 7 to 10 days. Five milliliters of $0.05 \%$ (wt/vol) Triton X-100 in sterile water were added to each dish, and spores were rubbed from the agar surface with a sterile glass rod. This high-density spore suspension was passed through two layers of cheesecloth, measured with a hemacytometer, and diluted with sterile water to achieve the desired inoculum density.

Continuous exposure to $0.3 \mathrm{ppm}$ ozone. A $90-\mathrm{W}$ corona discharge ozone generator (AgroCare, Model Oxtomcav XEE-245, Agroquality International, LLC, Bridgewater, $\mathrm{NJ}$ ) was installed in a $66.6 \mathrm{~m}^{3}$ cold storage room and set to maintain $0.3 \pm$ $0.05 \mathrm{ppm}(\mathrm{vol} / \mathrm{vol})$ ozone at $5 \pm 1{ }^{\circ} \mathrm{C}$ and 90 $\pm 5 \%$ relative humidity $(\mathrm{RH})$. The unit released ozone through a perforated 38.1$\mathrm{mm}$ diameter polyvinyl chloride (PVC) tube anchored to the ceiling of the room. The ozone concentration in the room was controlled and continuously monitored by a UV absorption ozone analyzer (Model IN-2000-1, INUSA Inc., Needham, MA) with a minimum detection limit of 0.01 ppm. Air from the ozonated cold storage room was pumped through a Teflon tube to the analyzer, which was located in an adjacent room. As a control, similar environmental conditions of temperature and $\mathrm{RH}$ were set in an ambient air atmosphere cold storage room. Ozone levels in this control room were periodically assessed with either a heated metal oxide ozone sensor (Model 21-Z, Eco Sensors Inc., Santa Fe, NM), with a minimum detection limit of $0.02 \mathrm{ppm}$, or a gas sampling pump (Sensidyne Model 800, Clearwater, FL) with detection tube no. $18 \mathrm{~L}$ and a minimum detection limit of $0.025 \mathrm{ppm}$. No measurable ozone was detected by either method during the entire storage period. Temperature and $\mathrm{RH}$ were continuously monitored in both rooms during the experiments. The desired RH was maintained in both rooms by an air-assisted low-pressure RH system, equipped with a computer-controlled humidity transmitter (Model HMD20VB, Vaisala, Inc., Helsinki, Finland). (i) In vitro mycelial growth. High-density spore suspensions of $P$. digitatum and $P$. italicum were prepared as previously described, and poured into sterile Erlenmeyer flasks with $50 \mathrm{ml}$ of potato dextrose agar (PDA) at $45^{\circ} \mathrm{C}$. The agar medium containing spores was quickly poured into empty sterile petri dishes and allowed to solidify. Cylinders of medium $(4.2 \mathrm{~mm}$ diameter) were cut with a sterile cork borer and each one placed on the agar surface in the center of a PDA petri dish. Six petri dishes per pathogen were prepared. Three partially open plates per pathogen (replicates) were held in both the ozone and the control rooms. After 4 days of exposure, the petri dishes from both rooms were covered with the lids and placed in an incubation chamber at $20 \pm 1^{\circ} \mathrm{C}$ and $90 \pm$ $5 \% \mathrm{RH}$ for an additional 5-day period.

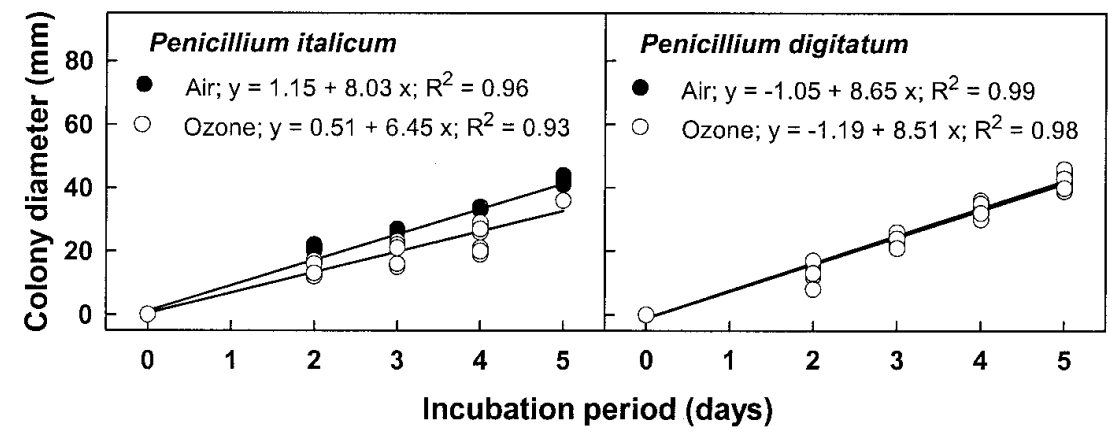

Fig. 1. Regression lines for the in vitro growth of Penicillium italicum and Penicillium digitatum during a 5-day incubation period at $20^{\circ} \mathrm{C}$ after 4 days of continuous exposure at $5^{\circ} \mathrm{C}$ to ambient air or 0.3 ppm ozone.

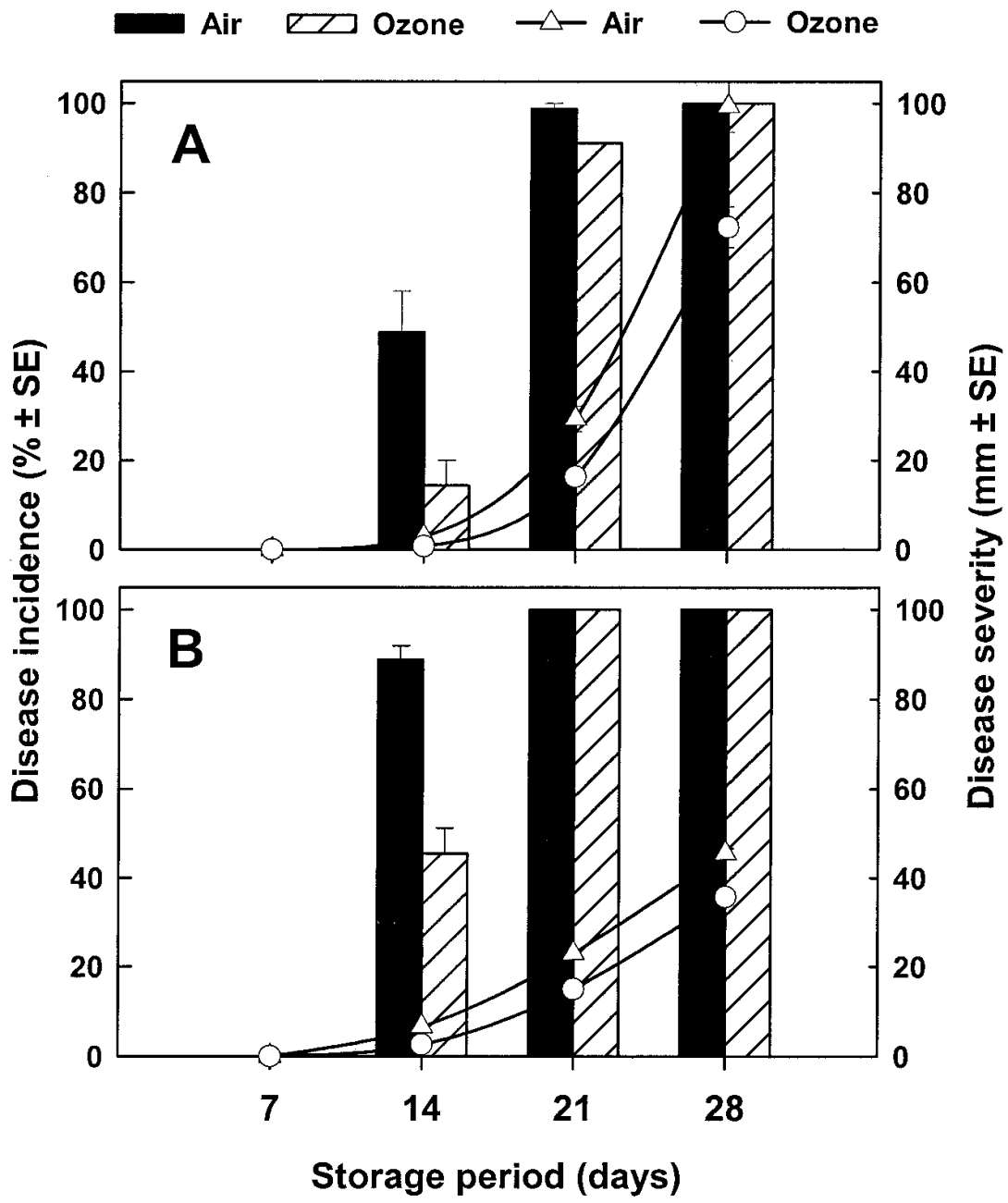

Fig. 2. Green (A) and blue (B) molds incidence (bars) and severity (lines) on artificially inoculated Valencia oranges continuously exposed for 4 weeks at $5^{\circ} \mathrm{C}$ and $90 \% \mathrm{RH}$ to ambient air or $0.3 \mathrm{ppm}$ ozone. 
Colony diameter and presence of spores were recorded daily. The experiment was conducted twice. In the second experiment, five replicates per pathogen were used.

(ii) Disease development. Valencia oranges were inoculated with $10^{6}$ spores $\mathrm{ml}^{-1}$ of $P$. digitatum or $P$. italicum by briefly immersing a stainless steel rod with a probe tip ( $1 \mathrm{~mm}$ wide by $2 \mathrm{~mm}$ in length) into the spore suspension and wounding each fruit once on the equator. The wound penetrated the albedo tissue but not the juice sacs, simulating natural inoculation. Inoculated fruit were placed in plastic cavity trays on open wooden trays that assured adequate gas contact. About $24 \mathrm{~h}$ after inoculation, five trays (replicates) of 18 oranges each were stored for 4 weeks in the ozone room, and five trays in the control room. Disease incidence and severity (lesion diameter), as well as external disease appearance, were recorded weekly. The experiment was conducted twice.

(iii) Inoculum density and fruit susceptibility. Environmental conditions in both the ozone and the control rooms were maintained at $20 \pm 1^{\circ} \mathrm{C}$ and $90 \pm 5 \%$ RH. Selected and randomized Valencia oranges were separated into two groups. Fruit in the first group were inoculated with $10^{4}$, $10^{5}$, and $10^{6}$ spores $\mathrm{ml}^{-1}$ of $P$. digitatum or $P$. italicum, as previously described. Fruit

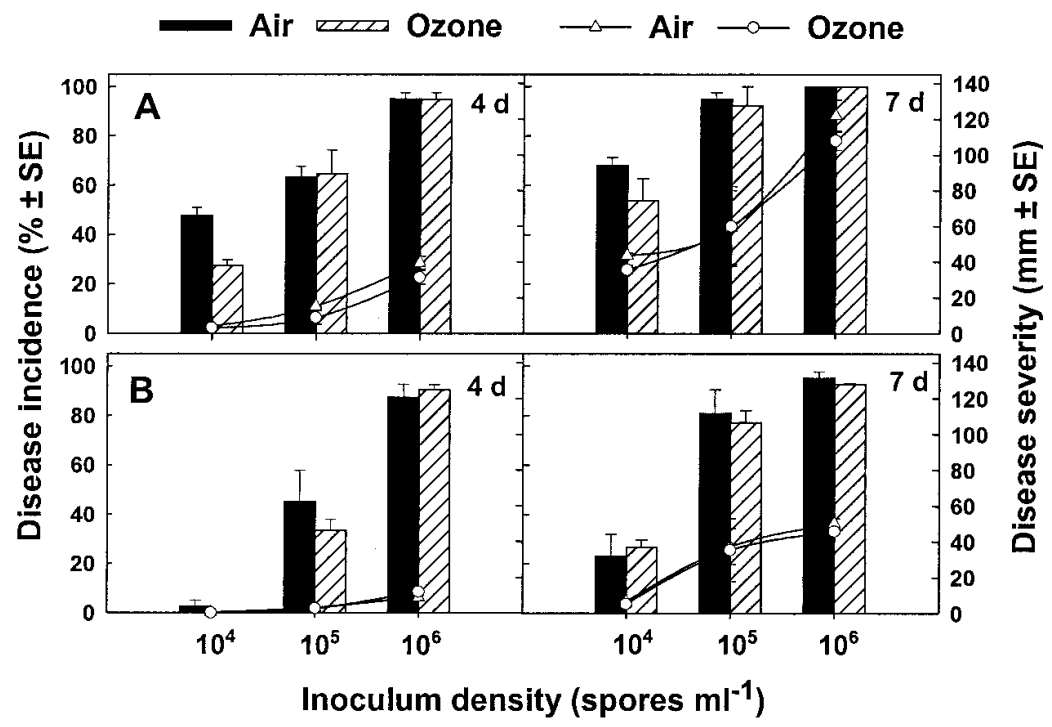

Fig. 3. Influence of inoculum density on the incidence (bars) and severity (lines) of green (A) and blue (B) molds on Valencia oranges exposed for 4 or 7 days at $20^{\circ} \mathrm{C}$ and $90 \%$ RH to ambient air or $0.3 \mathrm{ppm}$ ozone.

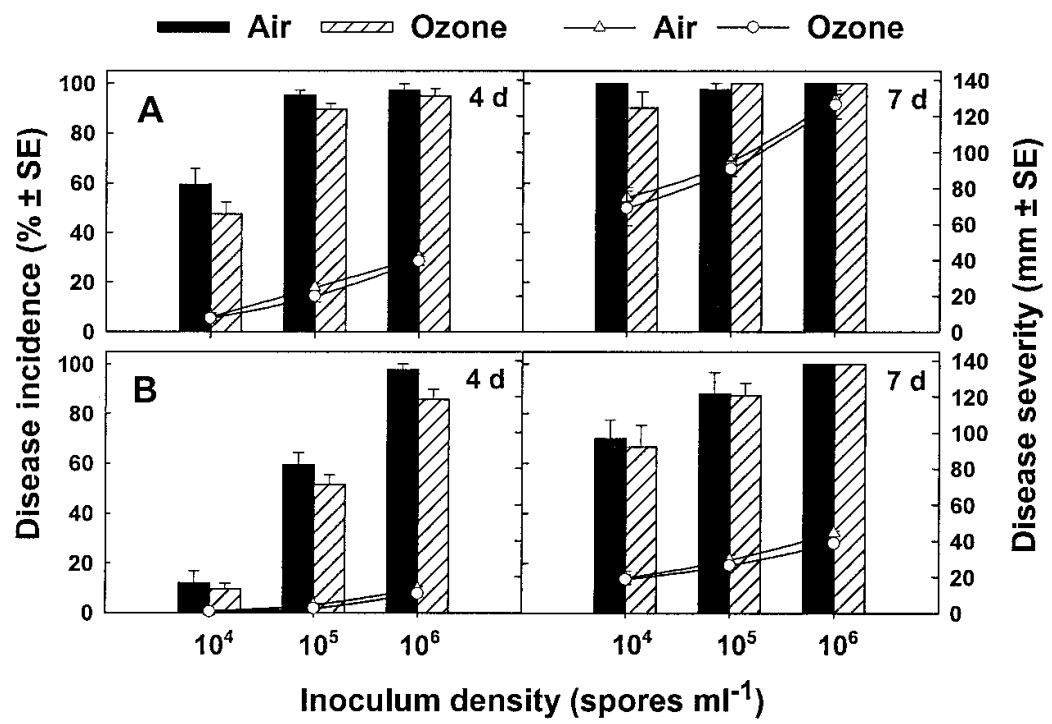

Fig. 4. Influence of continuous ozone exposure on the susceptibility of oranges to infection. Shown are green (A) and blue (B) molds incidence (bars) and severity (lines) on Valencia oranges exposed for 7 days at $20^{\circ} \mathrm{C}$ and $90 \% \mathrm{RH}$ to ambient air or $0.3 \mathrm{ppm}$ ozone, then artificially inoculated with different inoculum densities and incubated for 4 or 7 days at $20^{\circ} \mathrm{C}$ and $90 \% \mathrm{RH}$ in an ambient air atmosphere.

in the second group were not inoculated. For each treatment (combination of pathogen and inoculum density), half of fruit in each group were held for 7 days in the ozone room and half in the control room. Each treatment was applied to four trays (replicates) of 18 oranges each. Decay incidence and severity of inoculated fruit were recorded after 4 and 7 days of storage. After 7 days of storage, all fruit were removed from both rooms. In order to evaluate the possible effect of ozone exposure on the susceptibility of fruit to decay, fruit in the second group were then inoculated with $10^{4}, 10^{5}$, and $10^{6}$ spores $\mathrm{ml}^{-1}$ of $P$. digitatum or $P$. italicum and incubated for 7 days in the control room. Incidence and severity of green and blue molds were determined after 4 and 7 incubation days. The experiment was conducted twice.

Intermittent exposure to $0.3 \mathrm{ppm}$ ozone in a day-night cycle. A concentration of $0.3 \pm 0.01 \mathrm{ppm}$ ozone was generated at night in a $226 \mathrm{~m}^{3}$ commercial storage room. No ozone was generated during the day. The gas was generated with a water-cooled, corona discharge generator (Model CD-7, Del Industries, San Luis Obispo, CA) that produced $7 \mathrm{~g} \mathrm{~h}^{-1}$ of ozone at its maximum setting. The unit incorporated an oxygen concentration and air drier so the 3.5-liter $\mathrm{min}^{-1}$ output was composed of about $2 \%$ ozone with the balance being oxygen. The generator, located in an adjacent nonozonated room, was operated with a timer on a $12 \mathrm{~h}$ cycle. Ozone concentration in the ozone room was continuously monitored with an UV ozone analyzer (Model LC-400, PCI Wedeco Environmental Technologies Inc., New York, NY) with a minimum detection limit of 0.001 ppm. This monitor was located in the same room as the generator. Air from the ozonated cold storage room was pumped through a Teflon tube to the analyzer. The ozonated commercial storage room was maintained at $4.5 \pm 1^{\circ} \mathrm{C}$ and high $\mathrm{RH}$. Temperature was monitored with thermocouples connected to a data-logger. Control fruit were stored in a room of $30 \mathrm{~m}^{3}$ maintained at a similar temperature and high humidity. Ozone levels in this control room were periodically measured with the ozone sensor previously described. No ozone was detected during the storage period.

Eureka lemons were inoculated by injection of 100 fruit with $10^{5}$ spores of P. italicum $1.5 \mathrm{~cm}$ deep into the juice sacs. The fruit were randomly placed into four open boxes of 25 fruit each. Two of the boxes were placed in the ozonated storage room and two boxes were placed in the control room. The fruit were examined weekly. Sporulation was recorded for each fruit at each observation with an index from 0 to 5 . Numbers 1, 2, 3, 4, and 5, respectively, indicated 1 to $20 \%, 21$ to $40 \%, 41$ to $60 \%$, 61 to $80 \%$, and $>80 \%$ of the fruit surface covered with spores. The experiment was conducted twice; the fruit were stored for 8 
and 9 weeks in the first and second experiments, respectively.

Continuous exposure to $1.0 \mathrm{ppm}$ ozone. An ozone generator (Oxtomcav XEE-245) was installed in a $59.78 \mathrm{~m}^{3}$ refrigerated export container (Hyundai, Seoul, Korea, ID No. DFIU-320472-1). Ozone was released through 19-mm diameter perforated distribution PVC tubes placed in the T-channels of the container floor. Ozone concentration in the container was maintained to $1.0 \pm 0.05 \mathrm{ppm}$ at $10 \pm$ $1^{\circ} \mathrm{C}$ and continuously monitored with an UV ozone analyzer (IN-2000-1) located outside the container. Eureka lemons, inoculated $24 \mathrm{~h}$ before with $10^{5}$ and $10^{6}$ spores $\mathrm{ml}^{-1}$, and Valencia oranges, inoculated with $10^{6}$ spores $\mathrm{ml}^{-1}$ of $P$. digitatum and $P$. italicum, were placed in plastic cavity trays on open wooden trays and stored in the container for 2 weeks. For each pathogen and inoculum density, four trays (replicates) with 25 lemons each and four trays with 20 oranges each were used. As a control treatment, inoculated fruit were stored in a standard cold room at the same temperature. Ozone levels in this control room were periodically measured with the ozone sensor previously described. No ozone was detected during the storage period. Decay incidence and fruit sporulation were evaluated after 7 and 14 days of storage.

Ability to abate ethylene in an export container. The $59.78 \mathrm{~m}^{3}$ export container and the ozone equipment previously described were used in these trials. The temperature in the container was set to $0 \pm 1^{\circ} \mathrm{C}$ and the drain holes and air exchange vents were closed. The empty container was then vented and closed, and the initial ozone and ethylene levels determined. Ethylene from a gas cylinder was then introduced into the container. A pressure regulator and a rotometer (Model FM-1000, Matheson, Montgomeryville, PA) were used for controlling the flow of ethylene. When the ethylene concentration reached approximately $3.8 \mathrm{ppm}$, the ozone generator was turned on. Ethylene and ozone concentrations were measured hourly for a period of $5 \mathrm{~h}$, and again after $24 \mathrm{~h}$. Five relative ozone levels, designated as control (generator switched off), and levels 1, 2, 3, and 4 , were generated by different generator settings. Ethylene was measured by removing air from the ozone sample loop and then injecting the samples into a gas chromatograph equipped with a flame ionization detector (Carle AGC-211, EG\&G Chandler Engineering, Tulsa, OK).

Statistical analysis. For the in vitro tests, linear regression lines were fit to the radial growth values during the 5-day incubation period at $20^{\circ} \mathrm{C}$. Slopes of the lines were compared with a two-tailed Student's $t$ test $(P=0.05)$. Severity data (lesion diameter), the sporulation index, and the arcsine of the square root of the proportion of decayed fruit were analyzed with analy- ses of variance (SAS Institute Inc., Cary, NC). Mean comparisons were performed by Fisher's protected least significant difference (LSD) test $(P=0.05)$.

\section{RESULTS}

Continuous exposure to $0.3 \mathrm{ppm}$ ozone. (i) In vitro mycelial growth. None of the pathogen cultures exposed to 0.3 ppm ozone or to ambient air exhibited visible growth during the 4-day exposure period at $5^{\circ} \mathrm{C}$. Radial growth of $P$. italicum during the 5-day incubation period at $20^{\circ} \mathrm{C}$ was significantly reduced by the previous $0.3 \mathrm{ppm}$ ozone exposure at $5^{\circ} \mathrm{C}$ for 4 days (Fig. 1). In contrast, no differences in colony diameter were found for $P$. digitatum previously exposed to $0.3 \mathrm{ppm}$ ozone. Pathogen sporulation was not affected by the previous $0.3 \mathrm{ppm}$ ozone exposure. Spores of both $P$. digitatum and $P$. italicum were observed after a 2-day incubation period at $20^{\circ} \mathrm{C}$ in plates previously exposed to either ozonated or ambient air atmospheres.

(ii) Disease development. The incidence of both green and blue molds was significantly lower after 14 storage days at $5^{\circ} \mathrm{C}$, but not after 21 or 28 days, on inoculated oranges exposed to $0.3 \mathrm{ppm}$ ozone than on fruit exposed to ambient air (Fig. 2). Disease severity was also significantly lower under ozone after 21 days storage at $5^{\circ} \mathrm{C}$. The differences in lesion diameter after 28 days reached about $30 \mathrm{~mm}$ for green mold and $10 \mathrm{~mm}$ for blue mold (Fig. 2). Continuous exposure to $0.3 \mathrm{ppm}$ ozone affected external mycelial growth and sporulation of both pathogens. While powdery masses of olive green or blue spores were observed on decayed fruit exposed to ambient air, irregularly distributed masses of white mycelia that did not develop conidia were observed under $0.3 \mathrm{ppm}$ ozone.

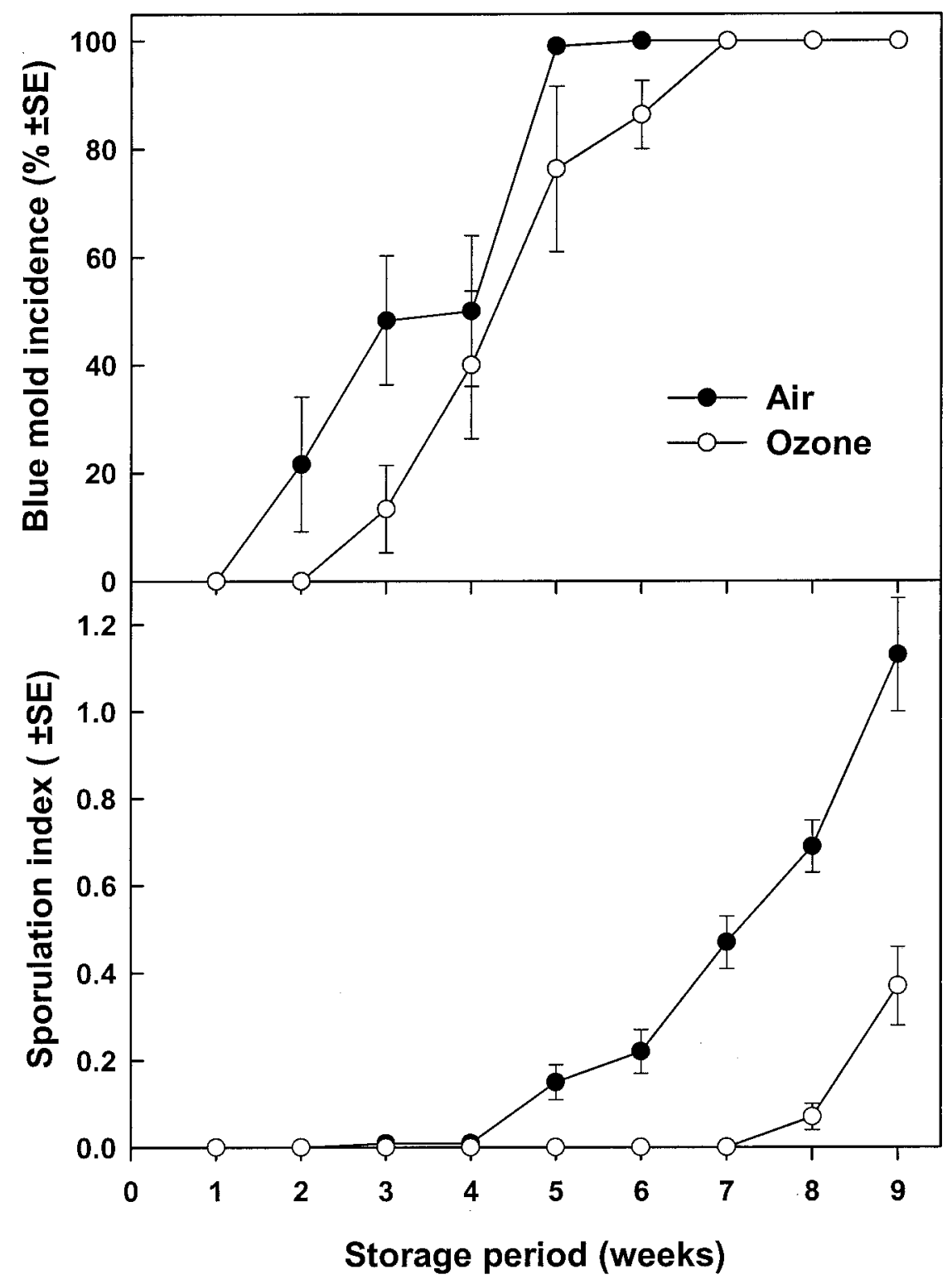

Fig. 5. Incidence of blue mold and sporulation among Eureka lemons artificially inoculated with Penicillium italicum and stored in a commercial storage room for 9 weeks at $4.5^{\circ} \mathrm{C}$ in an ambient air atmosphere or in a day-night ozone cycle (intermittent exposure to $0.3 \mathrm{ppm}$ ozone for $12 \mathrm{~h}$ ). 
Both species resumed normal surface cayed fruit from the ozone room that were incubated at $20^{\circ} \mathrm{C}$ and $90 \% \mathrm{RH}$ for 2 days. the fruit.

(iii) Inoculum density and fruit susceptibility. For both green and blue molds, and at all three inoculum densities tested, there were no significant differences in incidence or severity between oranges exposed to $0.3 \mathrm{ppm}$ ozone or to ambient air (Fig. 3). Both pathogens developed normal disease symptomatology and sporulated after 1 week storage under $0.3 \mathrm{ppm}$ ozone at $20^{\circ} \mathrm{C}$. Ozone exposure for 1 week at $20^{\circ} \mathrm{C}$ before inoculation did not affect susceptibility of oranges to either green or blue mold (Fig. 4). Even at the lowest spore concentration of $10^{4}$ spores $\mathrm{ml}^{-1}$, disease incidence and severity were not significantly different on fruit previously exposed to $0.3 \mathrm{ppm}$ ozone.

Intermittent exposure to $0.3 \mathrm{ppm}$ ozone in storage, the incidence of blue mold on artificially inoculated lemons was delayed, but not reduced, by a day-night ozone cycle. After 3 weeks of storage at $4.5^{\circ} \mathrm{C}$, it was about $15 \%$ and $50 \%$ on ozone-exposed and control fruit, respectively. However, it was $100 \%$ for both treatments after 7 weeks of growth and sporulated on samples of deOzone exposure did not noticeably injure a day-night cycle. In a commercial citrus

storage (Fig. 5A). In contrast, the sporulation of blue mold-infected lemons was greatly reduced by a day-night ozone cycle. A mean sporulation rating of about 0.5 and 1.1 was observed among control fruit after 7 and 9 weeks of storage, respectively, while the rating among ozone-exposed lemons was 0.0 and 0.4 , respectively (Fig. $5 \mathrm{~B})$. None of the fruit appeared injured by the ozone treatment.

Continuous exposure to $1.0 \mathrm{ppm}$ ozone. Decay incidence on lemons and oranges inoculated with $10^{6}$ spores $\mathrm{ml}^{-1}$ of $P$. digitatum or $P$. italicum was significantly lower among fruit exposed to 1.0 ppm ozone than among control fruit after 1 week of storage at $10^{\circ} \mathrm{C}$, but not after 2 weeks of storage (Table 1). Green mold incidence on lemons inoculated with $10^{5}$ spores $\mathrm{ml}^{-1}$ was significantly lower among fruit exposed to $1.0 \mathrm{ppm}$ ozone than among control fruit after either 1 or 2 weeks of storage. No significant differences were found for blue mold incidence on lemons inoculated with $10^{5}$ spores $\mathrm{ml}^{-1}$ (Table 1). Sporulation of both fungi at both inoculum densities was suppressed by ozone exposure. In every test, no surface injuries were observed on the fruit skin.

Ability to abate ethylene in an export container. Ethylene concentration within

Table 1. Influence of continuous exposure to ambient air or to $1.0 \mathrm{ppm}$ ozone on decay incidence on artificially inoculated Eureka lemons and Valencia oranges stored at $10^{\circ} \mathrm{C}$ in a $59.78 \mathrm{~m}^{3}$ export container

\begin{tabular}{|c|c|c|c|c|c|c|}
\hline \multirow[b]{3}{*}{ Fruit } & \multirow[b]{3}{*}{ Pathogen } & \multirow[b]{3}{*}{ Treatment } & \multicolumn{4}{|c|}{ Decay incidence $(\%)^{\mathrm{x}}$} \\
\hline & & & \multicolumn{2}{|c|}{$1 \times 10^{5 y}$} & \multicolumn{2}{|c|}{$1 \times 10^{6}$} \\
\hline & & & $7 d^{z}$ & 14d & $7 d$ & 14d \\
\hline \multirow[t]{4}{*}{ Eureka lemons } & P. digitatum & Air & $21 \mathrm{a}$ & $99 \mathrm{a}$ & $96 \mathrm{a}$ & $100 \mathrm{a}$ \\
\hline & & Ozone & $2 \mathrm{~b}$ & $71 \mathrm{~b}$ & $26 \mathrm{~b}$ & $95 \mathrm{a}$ \\
\hline & P. italicum & Air & $17 \mathrm{a}$ & $95 \mathrm{a}$ & $91 \mathrm{a}$ & $100 \mathrm{a}$ \\
\hline & & Ozone & $12 \mathrm{a}$ & $89 \mathrm{a}$ & $33 \mathrm{~b}$ & $92 \mathrm{a}$ \\
\hline \multirow[t]{4}{*}{ Valencia oranges } & P. digitatum & Air & $\ldots$ & $\ldots$ & $95 \mathrm{a}$ & $100 \mathrm{a}$ \\
\hline & & Ozone & $\ldots$ & $\ldots$ & $32 \mathrm{~b}$ & $94 \mathrm{a}$ \\
\hline & P. italicum & Air & $\ldots$ & $\ldots$ & $94 \mathrm{a}$ & $100 \mathrm{a}$ \\
\hline & & Ozone & $\ldots$ & $\ldots$ & $28 \mathrm{~b}$ & $99 \mathrm{a}$ \\
\hline
\end{tabular}

${ }^{\bar{x}}$ For each pathogen, values within columns followed by unlike letters are different according to a Fisher's Protected LSD test $(P=0.05)$ applied after an analysis of variance of the arcsine of the square root of the proportion of infected fruits. Non-transformed data are shown.

${ }^{y}$ Inoculum density (spores $\mathrm{ml}^{-1}$ ).

${ }^{\mathrm{z}}$ Storage period (days).

Table 2. Rate of ethylene reduction and concentration of ozone and ethylene resulting from the use of an ozone generator (Oxtomcav XEE-245) in an empty $59.78 \mathrm{~m}^{3}$ export container over a $24 \mathrm{~h}$ period after introducing an initial concentration of $3.8 \mathrm{ppm}$ of ethylene

\begin{tabular}{|c|c|c|c|}
\hline \multirow[b]{2}{*}{ Treatment } & \multirow[b]{2}{*}{ Ethylene reduction $\left(\mathbf{p p m ~} \mathbf{h}^{-1}\right)$} & \multicolumn{2}{|c|}{ Concentration after $24 \mathrm{~h}$} \\
\hline & & Ozone (ppm) & Ethylene (ppm) \\
\hline Control $^{\mathrm{x}}$ & 0.035 & 0.0 & 3.0 \\
\hline Generator Level 1 & 0.073 & 0.3 & 2.0 \\
\hline Generator Level 2 & 0.109 & 1.0 & 0.8 \\
\hline Generator Level 3 & 0.145 & 3.9 & 0.2 \\
\hline Generator Level 4 & 0.145 & $>10.0^{\mathrm{y}}$ & 0.0 \\
\hline
\end{tabular}

$\mathrm{x}$ Generator off.

${ }^{y}$ Concentration exceeded the range of the analyzer. the container decreased only slightly over the test period $\left(0.035 \mathrm{ppm} \mathrm{h}^{-1}\right)$ when the ozone generator was off (control, Table 2). The ozone generator reduced the ethylene level within the container, with the rate of reduction increasing as the generator setting was increased. At its highest settings (levels 3 and 4), the ozone generator reduced the ethylene level in the container at a rate of $0.145 \mathrm{ppm} \mathrm{h}^{-1}$, compared to 0.035 $\mathrm{ppm} \mathrm{h}^{-1}$ for the control (Table 2). Ozone concentrations in the container increased from the $0.0 \mathrm{ppm}$ ambient level (control) to $0.2,0.5,1.3$, and $2.1 \mathrm{ppm}$ for settings 1,2 , 3 , and 4, respectively, after $5 \mathrm{~h}$ (Fig. 6). After $24 \mathrm{~h}$, the ozone concentration in the container reached levels of $0.3,1.0$, and $3.9 \mathrm{ppm}$ for settings 1,2 , and 3 , respectively (Table 2 ). The ozone concentration exceeded the range of the analyzer (10.0 ppm) after $24 \mathrm{~h}$ with level 4.

\section{DISCUSSION}

In the in vitro tests, ozone neither killed all the spores nor adversely affected germination ability. Since the spores were located not only on the surface but also inside the agar cylinder, direct gas contact with all spores probably was not achieved. Similarly, Klotz (15) observed that ozone gas only partially inhibited the germination and growth of $P$. digitatum and $P$. italicum on agar, and that the cultures resumed their usual rapid rate of growth when they were removed from the ozone chamber, even after 3 weeks exposure. Hibben and Stotzky (12) concluded that spore sensitivity to the oxidizing action of ozone depended on the fungal species, spore morphology, substrate, moisture, and ozone dosage. Spore morphology could play some role on the differential activity of ozone against $P$. digitatum and $P$. italicum that was observed in our tests. No growth was noticed on the culture plates held in ambient air. Therefore, the lack of radial growth during exposure to $0.3 \mathrm{ppm}$ ozone at $5^{\circ} \mathrm{C}$ was due primarily to the low temperature and not to the presence of ozone. A longer exposure period was not used because in preliminary tests the PDA medium in the open culture dishes dried extensively.

In all experiments, exposure to gaseous ozone delayed the incidence of both green and blue molds on wound-inoculated oranges or lemons about 1 week. However, ozone was unable to control decay. Infections developed more slowly under ozone, but disease incidence at the end of the storage period was not reduced. Furthermore, we found no influence of inoculum density on the effect of ozone on both decay incidence and severity. The inability of ozone to control pathogens in wounds has been observed on naturally inoculated Valencia oranges (13) and artificially inoculated navel oranges (15) stored in an ozone atmosphere, and on artificially inoculated Valencia oranges treated with ozonated 
water (24). Likewise, ozone treatment did not control postharvest wound-infections on apples (22), pears (27), peaches $(25,26)$, or other commodities $(19,25,26)$. Apparently, fungal structures within wounds remain protected from the oxidizing effect of ozone because of limited ozone penetration, reduced ozone concentration as it reacts with fruit tissue or extracellular biochemicals, and/or the presence of antioxidants in the fruit. Some of these factors could also explain the failure of other strong oxidants, such as chlorine and chlorine dioxide, in controlling infections within inoculated wounds $(1,8,28)$. Since Penicillium molds are initiated by infections in wounds on the fruit surface, the efficacy of ozone in controlling green and blue molds cannot be predicted by the toxicity of ozone against free spores and hyphae. Therefore, ozone could not be a substitute for the synthetic fungicides that are currently applied on citrus fruit packinglines.

In our tests, despite the inability to control decay, ozone gas inhibited the normal aerial growth of the mycelia and greatly reduced sporulation from lesions among infected fruit once lesions developed. This was accomplished either with a continuous 0.3 or $1.0 \mathrm{ppm}$ ozone exposure or with a $0.3 \mathrm{ppm}$ day-night cycle. Harding (11) similarly observed control of sporulation and some control of decay by Penicillium molds on citrus fruit with continuous exposure to ozone at $1.0 \mathrm{ppm}$ for 15 days. We and Harding (11) observed that sporulation was suppressed only as long as ozone was present; lesions sporulated quickly when infected fruit were removed from the ozone atmosphere. The reduction of spore production has commercial value because stored fruit are usually treated with fungicides; if resistance develops among these pathogens, the ozone would reduce proliferation of resistant spores and presumably would prolong the useful life of postharvest fungicides. Furthermore, Penicillium spores that are produced from stored fruit are a significant source of contamination for healthy adjacent fruit, and for packages, walls, and floors of rooms. Storage under ozone could greatly reduce the load of airborne pathogenic spores. Schomer and McColloch (22) reported a strong reduction in spore load when apple storage rooms were ozonated. The contamination that can occur on packingline brushes and belts when citrus fruit are re-processed and packaged would also be reduced if infected fruit did not present sporulating lesions. The lack of sporulation, however, may make it more difficult for culling crews to see and remove infected fruit.

To be an effective anti-sporulant, ozone must penetrate into bins or boxes where fruit are stored. Harding (11) obtained good results with open boxes, whereas ozone penetration into cartons with small vents was unsatisfactory. We noticed that ozone was barely able to go through the plastic cavity trays used in some experiments. In tests not reported here, we oboranges stored in large plastic field bins that had large vents. The small storage boxes used for lemons are similarly well vented.

The susceptibility of Valencia oranges to decay was not affected by continuous exposure to $0.3 \mathrm{ppm}$ ozone. Since the fruit were exposed to ozone and then wounded and inoculated, this result suggests that the gas did not produce any mechanical damage to the albedo cells. Jin et al. (14) concluded that fruit senescence was delayed on Wenzhou mandarins exposed to ozone and negative ions, the respiratory intensity was lowered and the ethylene release rate decreased. Removal of ethylene in storage rooms or containers could delay fruit senescence and extend its posttained good suppression of sporulation on

harvest life. We and other workers $(6,21)$ found corona discharge ozone generators to be effective in reducing ethylene.

Ozone concentration in a storage room is dependent on the environmental conditions and on the fruit load. Ozone concentration rapidly decreases when temperature, humidity, or fruit load increases. Our results showed a synergistic effect between ozone and low temperature. While sporulation was effectively inhibited by a concentration of $0.3 \mathrm{ppm}$ ozone at $5^{\circ} \mathrm{C}$, it was not when the temperature was set at $20^{\circ} \mathrm{C}$. Ozone-generating technology today is accurate and reliable enough to provide and hold the desired ozone concentration in any storage room with use of correct equipment. Once the produce are stored at low temperature, only a few tasks taking a short time are required inside the storage rooms. The 0.3 ppm US-OSHA TLV-STEL concentration should minimize safety con-

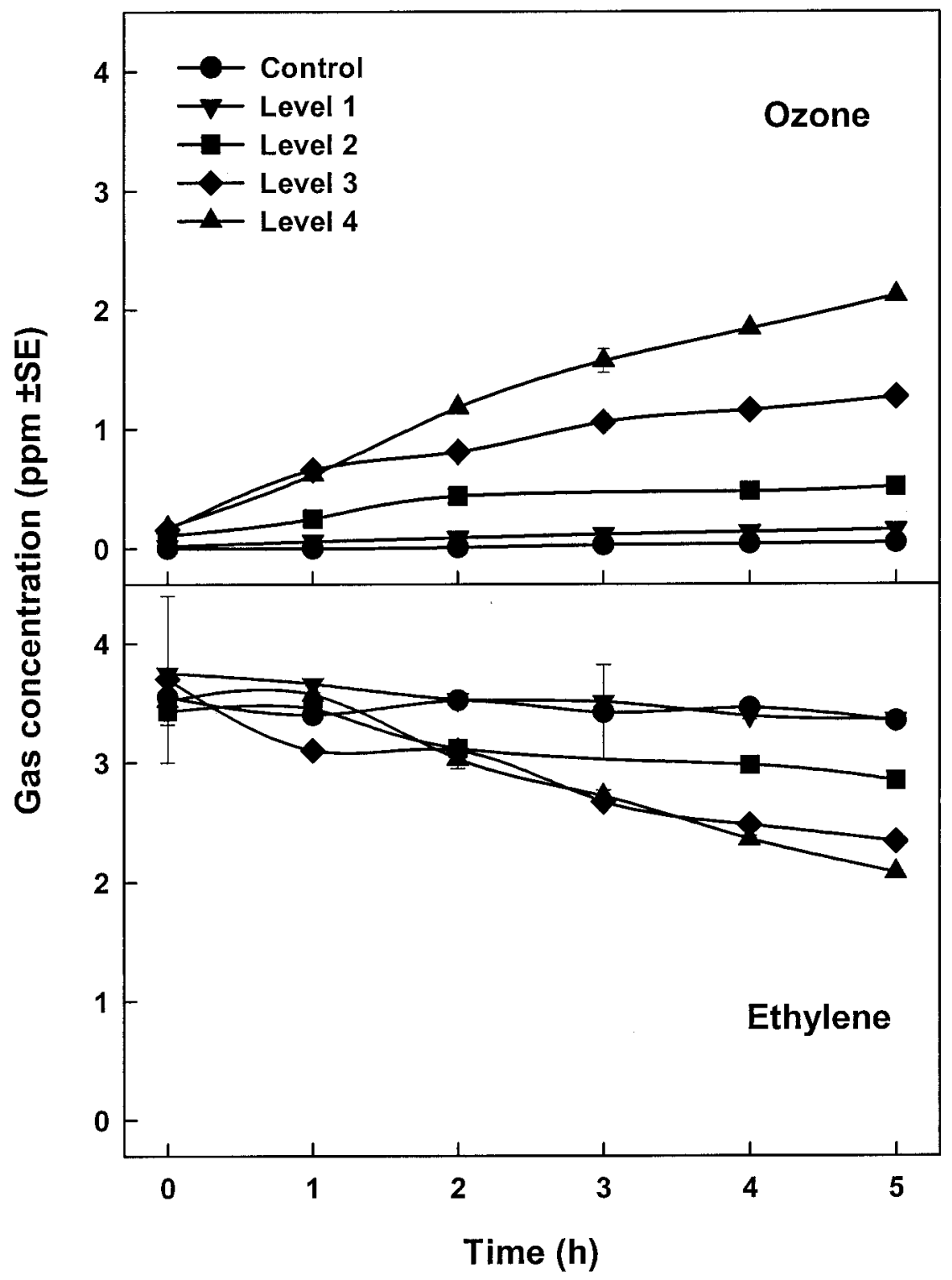

Fig. 6. Ozone and ethylene concentrations during a 5-h period resulting from the use of an ozone generator (Oxtomcav XEE-245) in an empty $59.78 \mathrm{~m}^{3}$ export container having an initial concentration of $3.8 \mathrm{ppm}$ of ethylene. 
cerns of workers and regulators about ozone use, and minimize the risk of injury to stored products. Exposure in a day-night cycle, in which no workers would normally be exposed to ozone, although brief entry would remain feasible and safe, may also be an alternative.

\section{ACKNOWLEDGMENTS}

We thank the Electric Power Research Institute (EPRI; Palo Alto, CA) for financial support. We also thank Agroquality International, LLC (Bridgewater, NJ), and Del Industries (San Luis Obispo, CA) for providing ozone equipment and technical assistance; Advanced Packinghouse Systems (Fresno, CA) for allowing us to use their citrus storage facilities, and Dole Inc. (Bakersfield, $\mathrm{CA}$ ) for providing the export container.

\section{LITERATURE CITED}

1. Adaskaveg, J. E. 1995. Postharvest sanitation to reduce decay of perishable commodities. Perishables Handling 82:21-25.

2. Baker, C. E. 1933. The effect of ozone upon apples in cold storage. Ice Refrig. 84:402404.

3. Barth, M. M., Zhou, C., Mercier, J., and Payne, F. A. 1995. Ozone storage effects on anthocyanin content and fungal growth in blackberries. J. Food Sci. 60:1286-1288.

4. Bus, V. G., Bongers, A. J., and Risse, L. A. 1991. Occurrence of Penicillium digitatum and Penicillium italicum resistant to benomyl, thiabendazole, and imazalil on citrus fruit from different geographic origins. Plant Dis. 75:1098-1100.

5. Dezman, D. J., Nagy, S., and Brown, G. E. 1986. Postharvest fungal decay control chemicals: treatments and residues in citrus fruits. Residue Rev. 97:37-92.

6. Dickson, R. G., Law, S. E., Kays, S. J., and Eiteman, M. A. 1992. Abatement of ethylene by ozone treatment in controlled atmosphere storage of fruits and vegetables. Pages 1-9 in: Proc. Int. Winter Meet. Amer. Soc. Agric. Engin. December 15-18, Nashville, TN.

7. Eckert, J. W. 1990. Impact of fungicide resis- tance on citrus fruit decay control. Pages 286302 in: Managing Resistance to Agrochemicals. From Fundamental Research to Practical Strategies. M. B. Green, H. M. Le Baron, and W. K. Moberg, eds. Amer. Chem. Soc. Symp. Ser. 421, Washington, D.C.

8. Eckert, J. W., and Eaks, I. L. 1989. Postharvest disorders and diseases of citrus fruits. Pages 179-260 in: The Citrus Industry. Vol. 5. W. Reuter, E. C. Calavan, and G. E. Carman, eds. University of California Press, Berkeley, CA.

9. García, J. M., Castellano, J. M., Nadas, A., and Olías, J. M. 1998. Effect of ozone on citrus storage. Pages 237-241 in: Proc. COST 914-COST 915. Workshop: Non Conventional Methods for the Control of Postharvest Disease and Microbial Spoilage. October 9-11, Bologna, Italy.

10. Graham, D. M., Pariza, M., Glaze, W. H., Newell, G. W., Erdman, J. W., and Borzelleca, J. F. 1997. Use of ozone for food processing. Food Technol. 51:72-76.

11. Harding, P. R., Jr. 1968. Effect of ozone on Penicillium mold decay and sporulation. Plant Dis. Rep. 52:245-247.

12. Hibben, C. R., and Stotzky, G. 1969. Effects of ozone on the germination of fungus spores. Can. J. Microbiol. 15:1187-1196.

13. Hopkins, E. F., and Loucks, K. W. 1949. Has ozone any value in the treatment of citrus fruit for decay? Citrus Ind. 30:5-7, 22.

14. Jin, L., Xiaoyu, W., Honglin, Y., Zonggan, Y., Jiaxun, W., and Yaguang, L. 1989. Influence of discharge products on post-harvest physiology of fruit. Pages 1-4 in: Proc. Int. Symp. High Voltage Engin., 6th.

15. Klotz, L. J. 1936. Nitrogen trichloride and other gases as fungicides. Hilgardia 10:27-52.

16. Krause, C. R., and Weidensaul, T. C. 1977. Effects of ozone on the sporulation, germination, and pathogenicity of Botrytis cinerea. Phytopathology 68:195-198.

17. Liew, C. L., and Prange, R. K. 1994. Effect of ozone and storage temperature on postharvest diseases and physiology of carrots (Daucus carota L.). J. Amer. Soc. Hortic. Sci. 119:563567.
18. National Research Council. 1993. Pesticides in the Diets of Infants and Children. National Academy Press, Washington, D.C.

19. Ogawa, J. M., Feliciano, A. J., and Manji, B. T. 1990. Evaluation of ozone as a disinfectant in postharvest dump tank treatments for tomato. (Abst.) Phytopathology 80:1020.

20. Pérez, A. G., Sanz, C., Ríos, J. J., Olías, R., and Olías, J. M. 1999. Effects of ozone treatment on postharvest strawberry quality. J. Agric. Food Chem. 47:1652-1656.

21. Rice, R. G., Farquhar, W., and Bollyky, L. J. 1982. Review of the application of ozone for increasing storage time for perishable foods. Ozone Sci. Eng. 4:147-163.

22. Schomer, H. A., and McColloch, L. P. 1948 Ozone in relation to storage of apples. USDA Circular 765:1-23.

23. Shimizu, Y., Makino, H., Sato, J., and Iwamato, S. 1982. Prevention of the rotting of grapes (Kyoho) in cold storage with the use of ozone. Res. Bull. Aichi-ken Agric. Res. Cent. 14:225-238.

24. Smilanick, J. L., Crisosto, C. H., and Mlikota, F. 1999. Postharvest use of ozone on fresh fruit. Perishables Handling 99:10-14.

25. Spalding, D. H. 1966. Appearance and decay of strawberries, peaches, and lettuce treated with ozone. ARS-USDA Marketing Res. Rep. 756.

26. Spalding, D. H. 1968. Effects of ozone atmospheres on spoilage of fruits and vegetables after harvest. ARS-USDA Marketing Res. Rep. 801.

27. Spotts, R. A., and Cervantes, L. A. 1992. Effect of ozonated water on postharvest pathogens of pear in laboratory and packinghouse tests. Plant Dis. 76:256-259.

28. Spotts, R. A., and Peters, B. B. 1980. Chlorine and chlorine dioxide for control of d'Anjou pear decay. Plant Dis. 64:1095-1097.

29. U.S. Food and Drug Administration. 1997. Substances generally recognized as safe, proposed rule. Federal Register 62:18937-18964.

30. Whiteside, J. O., Garnsey, S. M., and Timmer, L. W., eds. 1988. Compendium of Citrus Diseases. 2nd ed. American Phytopathological Society, St. Paul, MN. 